\title{
GESTÃO ACADÊMICA
}

A professora Valesca Reichelt, da Universidade Luterana do Brasil (ULBRA), selecionou livros sobre gestão na educação superior brasileira. A alta competitividade nesse setor ocorre devido ao aumento do número de instituições e de cursos oferecidos, bem como à desaceleração da demanda por vagas. Ainda, os sistemas de avaliação do Ministério da Educação permitem à sociedade e aos estudantes compará-las na contratação dos serviços. Assim, deve-se ampliar a gestão da qualidade de ensino para além dos aspectos pedagógicos, adicionando a ela questões mercadológicas, estratégicas e de sustentabilidade, até então restritas ao ambiente empresarial.

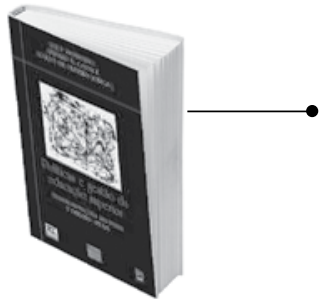

POLÍTICAS E GESTÃO DA EDUCAÇÃO SUPERIOR: transformações recentes e debates atuais. Luiz F. Dourado, Afrânio M. Catani e João F. de Oliveira (Org). São Paulo: Xamã, 2003. 240 p.

O livro compila trabalhos de diversos autores, voltados para a relação entre Estado, sociedade e mercado, bem como seus desdobramentos no que tange às políticas de gestão e regulação da educação superior. Aborda também as questões relativas à expansão acadêmica pública e privada, avaliações institucionais, trabalho docente, gestão da qualidade e espaço para a produção do conhecimento.

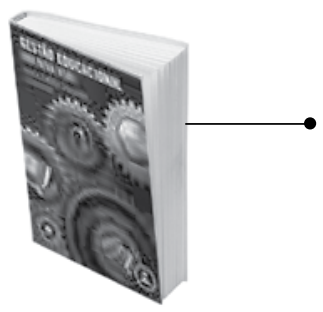

GESTÃo EDUCACIONAL: uma nova visão. Sônia Simões Colombo (Org). Porto Alegre: Artmed, 2004. 262 p.

O livro reúne mantenedores, executivos e consultores educacionais com experiência em gestão de instituições de ensino. As quatro partes da obra abordam os aspectos mais relevantes para essas instituições, tais como as gestões administrativa, econômico-financeira e acadêmica, bem como as especificidades existentes no ensino superior. Um dos aspectos discutidos é como as IES têm se atualizado frente às forças externas e internas que exercem influência sobre a empresa-escola.

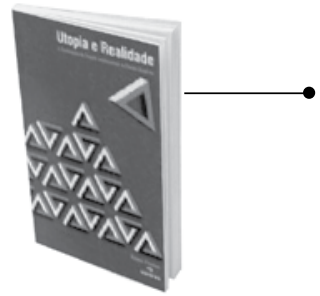

UTOPIA E REALIDADE: a construção do projeto institucional no ensino superior. Édson Franco. Brasília: Universa, 1998. 149 p.

O autor aborda a questão do projeto institucional em diferentes contextos, frente às necessidades sociais, às exigências do mercado de trabalho globalizado e ao desenvolvimento do ser humano. São abordadas ainda a melhoria da qualidade do ensino superior, a avaliação institucional e a valorização da experiência profissional. A construção do projeto institucional é apresentada como caminho obrigatório a trilhar na busca constante de soluções na relação universidade-aluno-empresa-comunidade-Estado.

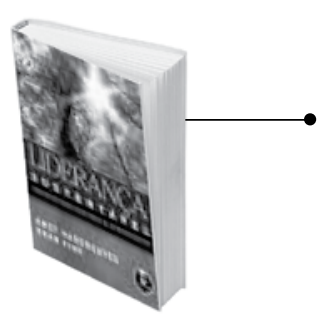

LIDERANÇA SUSTENTÁVEL: desenvolvendo gestores da aprendizagem. Andy Hargreaves e Dean Fink. Porto Alegre: Artmed, 2007. 248 p.

Direcionado prioritariamente para gestores escolares, o livro aborda um dos aspectos mais importantes e freqüentemente negligenciados da liderança: a sustentabilidade. Sendo sustentáveis, as instituições trariam educação e liderança de melhor qualidade, o que beneficiaria os estudantes por um longo tempo. Os autores propõem sete princípios para a liderança sustentável: profundidade da aprendizagem, durabilidade, amplitude, justiça, diversidade, engenhosidade e conservação.

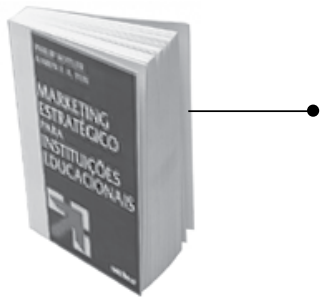

MARKETING ESTRATÉGICO PARA INSTITUIÇões EdUCACIONAIS. Philip Kotler e Karen F. A. Fox. São Paulo: Atlas, 1998. 448 p.

Com a expansão vertiginosa do número de instituições de ensino superior no Brasil a partir de 1995, tornou-se imperativo o uso de estratégias mercadológicas tanto para atrair novos estudantes como para retê-los até o final do curso, evitando a evasão. Este livro aborda os problemas mercadológicos enfrentados por instituições educacionais e as formas de utilização de estratégias de marketing capazes de saná-los ou minimizá-los. 